\title{
The perceptions of non music staff and senior management of the impact of the implementation of the Musical Futures approach on the whole school
}

\begin{abstract}
This research aimed to provide an account of the impact of the Musical Futures approach on the wider school community in Musical Futures 'Champion Schools'. Questionnaires were completed by 344 non-music teachers. Interviews were undertaken with members of senior management teams. The majority of staff indicated that Musical Futures had had a positive impact on student motivation, well-being, self-esteem and confidence and had encouraged students to work together. There was less agreement that it had improved student concentration, organisation and students' attitudes towards learning and academic progression. The interviews provided deeper insights into the issues relating to implementation.
\end{abstract}

\section{Key words Musical Futures, Impact, informal learning, teachers, senior management}

\section{Introduction}

In recent years concerns have been expressed about the relevance of school music to young people in England with some suggesting that music should be an extracurricular activity (Sloboda, 2001). In the Nordic countries, particularly Sweden, the relevance of school music was addressed during the 1960 s as part of more general education policy which focused on the entitlement of each student to have his or her individual needs and interests recognised in school. In music this led to greater links being made between students' extra-curricular music activities and the activities that they undertook in the classroom. Popular music became part of the compulsory school music curricula in the 1970 s and typically was taught using informal learning processes mirroring those adopted by popular musicians (Karlsen \& Vakeva, 2012). 
In the UK, the adoption of informal learning practices in school music has been more recent than in the Nordic countries and has been driven largely by the Musical Futures approach. This was designed to devise new and imaginative ways of engaging young people, aged 11-19, in musical activities, providing all children with opportunities to engage with music that reflected their interests while also empowering them in taking control of their musical learning (Finney \& Philpott, 2010). Musical Futures was launched in 2003 and emerged from research which focused on how musicians working in popular genres learned through listening and playing by ear (Green, 2002; 2008). As in the Nordic countries student centred pedagogies were developed. Teachers facilitated learning rather than directing it with pupils participating in determining the nature of the curriculum. The original pilot work took place between 2004 and 2006 in three Local Authority Music Services with four key strands emerging. Informal Music Learning at Key Stage 3 was based on the real-life learning practices and processes of popular musicians, enabling students to learn alongside friends, through independent, self-directed learning with teachers acting as facilitators and musical models. The Whole Curriculum Approach, a scheme of work for Year 8 students who had not previously experienced sustained musical engagement included extra support for the teacher, bringing informal learning processes into schools, making tangible connections with students' musical lives outside school, and involving students in real musical activity, in genuine musical situations and environments. Personalising Extra-Curricular Music provided guidance on personalising extra-curricular music projects so that they complemented the curricular work in schools and enhanced students' musical progression, while NUMU ( $\underline{\text { www.numu.org.uk }}$ ) was an interactive web space for creating music, publishing, marketing and promoting, allowing students to develop skills and apply them to a real life situation with a global audience. Following this initial work a toolkit of teacher resources was published which included a wide range of materials - lesson plans, National Curriculum mapping, video and audio material, case studies and quotes from participants, students and teachers (www.musicalfutures.org). Following this initial work, a twoyear Continuing Professional Development (CPD) programme was offered and in 2008 a national 
network of 'Champion Schools' was established. These adapted and adopted Musical Futures independently (d'Amore, 2014).

Since its initial conceptualisation the programme has developed based on increasing knowledge of how teachers adapt and apply the pedagogy in a range of classroom situations. Two key areas have been identified. The first is informal learning, where students determine their own targets and learn through self-directed activities starting with familiar music, moving on to other genres and ultimately composition. The teacher's role is to model, support, advise and guide. The second approach is non-formal teaching which is based on community music practice where fully inclusive group-based activities in performing, listening, composing and improvising are undertaken with teachers and students co-constructing content. These developments have led to a new definition of Musical Futures as 'an approach to teaching and learning.... a new way of thinking about musicmaking in schools that brings non-formal teaching and informal learning approaches into the more formal context of schools (Musical Futures, 2014, p 9).

Most evaluations of the implementation of the Musical Futures approach to teaching music have focused on the impact on students and their learning in music and have been broadly positive indicating enhanced motivation and enthusiasm for music (see Benson, 2012; Evans, Beauchamp \& John, 2015; Jeanneret, 2010; John \& Evans, 2013; Ofsted, 2006; O’Neill \& Bespflug, 2011; Younker et al., 2012). There have been fewer evaluations of the implications for music teachers an exception being the work of Jeanneret, McLennan \& Stevens-Ballenger (2011).

In the Nordic countries where informal, student centred learning based on popular music has been in place for many years it has been possible to consider the longer term implications. Firstly, students, while indicating that they enjoy school music report that they find it old fashioned and indicate that it excludes many contemporary genres (Skolverket, 2004). Generally, computers and DJ equipment is not available and very few young people compose their own music (Georgii- 
Hemming, 2006). Vakeva (2010) has suggested that the approach needs to be expanded to include a wider variety of musical cultures, although issues have been raised about the appropriateness of including some popular music which may be sexist or aggressive in the school music curriculum (Vakeva, 2006), . Inevitably, as teachers design their own curriculum, taking account of the leisure activities of their students, there is large variability between schools (Georgii-Hemming and Westvall, 2010). Perhaps the most serious criticism is the lack of progression of the students. Teaching tends to be short-term, unplanned and populist with many one-off activities which contribute to a lack of continuity (Georgii-Hemming and Westvall, 2010; Skolverket, 2004). Teachers are more familiar with their students' musical preferences and leisure activities but this mainly benefits those who play instruments (Skolverket, 2004). There are still some groups of students whose needs are not met and who tend to become disengaged (Bergman, 2009). These limitations have led to considerable debate as to whether music education has become too individualised and informal and whether there should there be a better balance between formal and informal learning (Georgii-Hemming and Westvall, 2012).

In the Nordic countries informal learning in music was adopted as part of a more general policy agenda relating to the whole school curriculum. In contrast, Musical Futures was developed in an educational context where education was seen to be a means of equipping the population with the knowledge, skills and innovative potential required to compete in $21^{\text {st }}$ century knowledge economies (OECD, 2007) leading to an emphasis on the outcomes of examinations (Paynter, 2000) an agenda which has come to be known as 'performativity' (Ball, 2003). As Musical Futures has developed in this context, there are questions about the extent to which the informal, student led approach is seen to benefit students, not only musically, but more broadly and whether the adoption of informal methods in music lessons has impacted on the school more generally. Although a substantial number of teachers are implementing the Musical Futures approach (about 700 in 2008, see Hallam et al., 2008) little is known about the perceptions of non-music school staff and senior 
management about the impact on students and the school more generally. This paper addresses this issue. The specific research questions were:

- To what extent are non-music staff in Musical Futures champion schools aware of the implementation of the Musical Futures approach?

- To what extent do non-music staff in Musical Futures champion school perceive that the implementation of Musical Futures has had an impact on students' motivation, well-being, self-esteem, team working, confidence and independent working?

- To what extent do non-music staff in Musical Futures champion schools perceive that the implementation of Musical Futures has had an impact on concentration, attitudes towards learning, organisational skills and academic progression?

- To what extent do staff perceptions of the above change over time?

- What is the perceived impact of Musical Futures, amongst members of school senior management teams? What are its perceived strengths and weaknesses?

\section{Methods}

Research design: A mixed methods research design was adopted including questionnaires, to enable the collection of the perceptions of Musical Futures from a wide range of non-music staff, and semi-structured interviews with members of the Senior Management Team, to provide in depth insights into the impact, if any, on the school as a whole.

The research was carried out over a three year period in three phases to explore whether there was change in the impact of the implementation of the Musical Futures approach over time. The research design was based on the participation of six Musical Futures Champion schools. To allow for attrition in the completion of the questionnaires, two additional schools were recruited at the start of the research. During Phase 1, staff from all eight schools completed the questionnaire. One school dropped out after Phase 1. Phases 2 and 3 included the remaining seven schools. 
Members of the senior management team in the planned six case study schools were interviewed in Phases 1 and 2.

The case study schools: All of the case schools were Musical Futures Champion schools where it was expected that the profile of Musical Futures would be greater than in non-champion schools increasing the likelihood that non-music staff and the Senior Management Teams would be aware of Musical Futures and its possible impact. The case study schools were selected in consultation with the Musical Futures team to represent different types of school and lengths of experience with Musical Futures.

School A was a larger than average community secondary school, co-educational, with 1416 students aged 11-18 on roll. 260 of these comprise the sixth form. School A was a Specialist Technology College and a Beacon School. Details of the makeup of the student population are set out in Table 1. The school had adopted the Musical Futures approach three years prior to the research. It was implemented through informal learning, mainly in Year 9, using two large units: one where the students produced a cover version of a song, the other where they wrote a song. Prior to Year 9 students developed musical skills in Years 7 and 8 learning to play the guitar, keyboard, drums or singing. The Musical Futures approach was continued in Years 10 and 11 when the students moved on to take Business and Technology Education Council (BTEC) qualifications. Cross curricular themes had also been developed. The school as a whole was perceived by music staff as open to trying out new ideas, focusing on the students and supporting them to fulfil their potential personally and academically. This ethos was perceived as being supportive to Musical Futures.

School B was a single-sex community comprehensive school, with Specialist Arts College status. There were 1447 boys aged 11-19 on the school roll, with 248 of these comprising the sixth form. Details of the student population are set out in Table 1. The Musical Futures approach was adopted 
in Year 8 and Year 9. In Year 9, students worked in groups to copy a CD of a popular song, initially chosen by the teacher with students making their own choices later. Project work with the support of a community musician also contributed to the development of musical skills as did the support of peripatetic teachers. Young people went on to take BTEC qualifications in music not the General Certificate of School Education (GCSE). This approach continued in Year 12 where students took BTEC level 3. The music staff viewed the school as offering equal opportunities to all, valuing all. There were opportunities and structures in place for students to get extra help if they needed it or to work independently if they believed that they could take something further. Musical Futures reflected the focus in the school of listening to the student voice and getting more feedback from the students about the aims of lessons and their content. Music staff had presented information about Musical Futures and how it worked to other staff in the school and how it might be adapted for other subjects.

School C was a Community Secondary School with Academy status. There were 1790 students aged 11-18 on the roll, with 485 of these comprising the sixth form. The school was co-educational and had Specialist Language and Technology status. Table 1 sets out further details of the student population. There was a clear expectation from staff that students would achieve to their potential. The school prided itself on fostering the highest standards of pastoral and academic care. Musical Futures was mainly adopted in years 8 and 9. Students were supported in gaining some basic skills on the guitar and in Year 9 whole class compositions were introduced using riffs and more instruments, e.g. glockenspiels and xylophones. Year 8 had a carousel approach with students learning parts of songs chosen for them and also composing music for a film. The skills developed through this supported being in a band in Year 9.

School D was a co-educational, community secondary school with a specialism in science. There were 1286 students aged 11-16, on the school roll. Details of the student population are set out in Table 1. There was strong pastoral support for students in the school and a common positive 
approach to meeting challenges. At the school, all years (7-9) were involved in Musical Futures. The school focused mainly on 'band work' with students learning a piece of music that they had been given then creating a composition based on what they had learned, extending and elaborating it. During the research there were a number of challenges faced by the department including changes in staff and extensive building work, both of which affected the experience of students in music lessons. Not all staff engaged with the Musical Futures programme. Some staff preferred to adopt a mixture of approaches particularly with years 10 and 11. There were plans to offer AS Music Technology for students who did not have the skill set for traditional A Level as there was a relatively low level of take up of instrumental tuition to a high level. Music staff felt that there was a lack of understanding of the nature of the Musical Futures programme across the school.

School E was a mixed gender community comprehensive school, with students aged 11-18. There were 1223 students on the school roll, in total, with 183 of these comprising the sixth form. Detailed information about the school population is set out in Table 1. The school had high quality pastoral care and provided extensive extra-curricular opportunities for students. Musical Futures was implemented in Year 9 and adapted to meet the needs of the school with the ethos and overall principles integrated into the whole department as far as possible. During the research there were significant changes in staffing in the music department. The Musical Futures approach with its focus on independent learning contrasted with the more directed teaching in the rest of the school. The music staff did not feel that they were supported by the senior management team as Musical Futures was viewed as too innovative.

School F was a Church of England mixed gender non-selective school with Specialist Visual Arts College Status. There were 956 students aged 11-18 on the roll, with 234 of these comprising the sixth form. Details of the school population are set out in Table 1. The school aimed to nurture and educate students to achieve their potential and be valuable members of society. At the time of the research Musical Futures had only recently been introduced. It was implemented initially with Year 
8 with students learning to copy a CD through playing by ear. Within the school a very academic approach to learning was adopted which music staff perceived as creating a very positive learning environment where dignity and respect for others was central. Musical Futures had a high profile in the school because of the musical performances in assemblies and concerts including classical and popular music. Despite the high profile of music in the school, most non-music staff were perceived as being unaware of Musical Futures.

School G was a Community High School and Arts College with specialist visual arts status. There were 806 pupils on the roll, aged 11-16. Table 1 provides more detail about the student population. The school was a specialist visual arts college. School staff had high expectations for student attainment which ensured that students were well prepared for employment and further study. The Head of Music had implemented Musical Futures but other staff (part time teachers or trainee teachers) varied in their confidence with Musical Futures so the approach was not implemented consistently.

Table 1: Case study schools

\begin{tabular}{|c|c|c|c|c|c|c|c|}
\hline School & $\begin{array}{l}\text { Specialist } \\
\text { status }\end{array}$ & $\begin{array}{l}\text { Number } \\
\text { on roll }\end{array}$ & $\begin{array}{l}\text { Ethnic make } \\
\text { up }\end{array}$ & FSM & EAL & $\begin{array}{l}\text { OFSTED } \\
\text { grade }\end{array}$ & $\begin{array}{l}\text { Music } \\
\text { exams } \\
\text { taken in } \\
\text { KS4 }\end{array}$ \\
\hline School A & Technology & 1416 & $\begin{array}{l}\text { Mainly White } \\
\text { British }\end{array}$ & Low & Low & Satisfactory & BTEC \\
\hline $\begin{array}{l}\text { School B } \\
\text { Boys school }\end{array}$ & Arts & 1447 & $\begin{array}{l}\text { Over } 50 \% \text { black } \\
\text { and minority } \\
\text { ethnic } \\
\text { backgrounds }\end{array}$ & High & High & Good & BTEC \\
\hline School C & $\begin{array}{l}\text { Language and } \\
\text { technology }\end{array}$ & 1790 & $\begin{array}{l}\text { Mainly White } \\
\text { British }\end{array}$ & Low & Low & Outstanding & GCSE \\
\hline School D & Science & 1286 & $\begin{array}{l}\text { Mainly minority } \\
\text { ethnic } \\
\text { backgrounds }\end{array}$ & High & High & Satisfactory & BTEC \\
\hline School E & Science & 1223 & $\begin{array}{l}\text { Mainly White } \\
\text { British }\end{array}$ & Low & Low & Satisfactory & $\begin{array}{l}\text { GCSE } \\
\text { Rockschool }\end{array}$ \\
\hline School F & Visual arts & 956 & $\begin{array}{l}\text { Mainly White } \\
\text { British }\end{array}$ & Low & Low & Outstanding & GCSE \\
\hline School G & Visual arts & 806 & $\begin{array}{l}\text { Mainly White } \\
\text { British }\end{array}$ & Low & Low & Outstanding & GCSE \\
\hline
\end{tabular}

$* \mathrm{FSM}=$ free school meals; $\mathrm{EAL}=$ English as an additional language 
The sample: Questionnaires were administered three times over the course of the research to establish if there was any change in perceptions of Musical Futures by non-music staff the longer the approach was implemented. In total, across the three phases of data collection, 344 non-music staff completed questionnaires.

During Phase 1, 297 non-music staff completed questionnaires. The numbers completing the questionnaires in each school ranged from 28 to 67 . Four head teachers completed the questionnaire, 16 assistant or deputy heads, 16 year heads, and a range of other senior management team members. Sixty three respondents were heads of departments other than music. Questionnaires were completed by 139 teachers and 61 with other roles including learning and support staff, Special Educational Needs Co-ordinators (SENCOS) and non teaching staff, e.g. receptionist.

When the schools were revisited in Phase 2, 88 non-music staff completed the same questionnaire again. These responses came from four schools, with numbers from each school ranging from 16 to 20. The responses came from a wide range of staff, including two deputy head teachers, eight heads of year and eleven subject department heads. The others were subject teachers, pastoral staff, library staff and technicians.

Finally, in Phase 3, 54 of the non-music staff from three schools completed the questionnaire. The number of responses from each school ranged from six to 27 and represented senior management, subject leaders and subject teachers and pastoral staff.

Forty-four non-music staff from four schools completed the questionnaire in Phase 1 and Phase 2 including two deputy head teachers, five heads of year, seven subject department heads, 25 subject teachers and a number of other library, pastoral and support staff. Twenty-three staff members completed the questionnaire at Phase 1 and Phase 3 including responses from three deputy heads, 
four heads of year, nine subject department heads and seven subject teachers. Changes over time are explored in the paper using these samples.

In Phase two of the research interviews were undertaken with seven members of the senior management teams in the schools.

The questionnaire: Given the time pressures which teachers are under, the questionnaire for nonmusic staff was designed to be quick (about five minutes) and easy to complete. For this reason it was made up of Likert scale type statements which were positively phrased with teachers asked the extent to which they agreed with them. The minimum of personal information was required only to enable matching of questionnaire data over the three phases of the research, Teachers were asked about the extent to which they had knowledge of the Musical Futures approach, the extent to which they believed Musical Futures had had a positive impact on the whole school, and the extent to which they believed that Musical Futures had had a positive impact on pupil motivation, well-being, self-esteem and progression; had encouraged pupils to work together and without help; and had increased confidence, concentration, organisation and attitudes to learning in general. Teachers were also given the opportunity to add written comments. The actual statements in the Likert scale are set out in the presentation of the findings. Cronbach's Alpha was calculated to establish the internal reliability of the scale. There was a very high level of reliability, .941 .

The interview schedule: The interviews with the members of the Senior Management Teams (SMT) in the schools were designed to assess the extent to which they were aware of the implementation of Musical Futures in their school and their perception of the impact that Musical Futures had had in the school in relation to the students and the wider school environment. The interview questions are set out in the appendices. 
Analysis of data: The questionnaire data were analysed using SPSS. Percentage responses and means were calculated and Analysis of Variance undertaken to explore differences between schools.

The interviews were transcribed in full. Inductive analysis of the interview data was undertaken, characterised by a coding of the data with no pre-existing frame of reference. The analysis was data-driven and themes were allowed to emerge from the data (Patton, 1990; Braun and Clarke, 2006). The findings from the interview data are presented within the context of each of the six Champion schools where interviews were undertaken.

\section{Findings}

\section{Knowledge of Musical Futures}

At Phase 1, of those responding to the questionnaire, 149 non music staff (50\%) reported knowing nothing about Musical Futures, 53 (18\%) reported not knowing much about it, 78 (26\%) reported knowing something about it and 5\% a lot about it. An analysis of variance showed highly statistically significant differences in the responses of different schools $(\mathrm{p}=.0001)$ (see Figure 1). The bars represent the mean score for knowledge of Musical Futures where $0=$ no knowledge and 4 $=$ knows a lot about it.

Figure 1: Mean scores of knowledge of Musical Futures amongst non-music staff (Phase 1) 


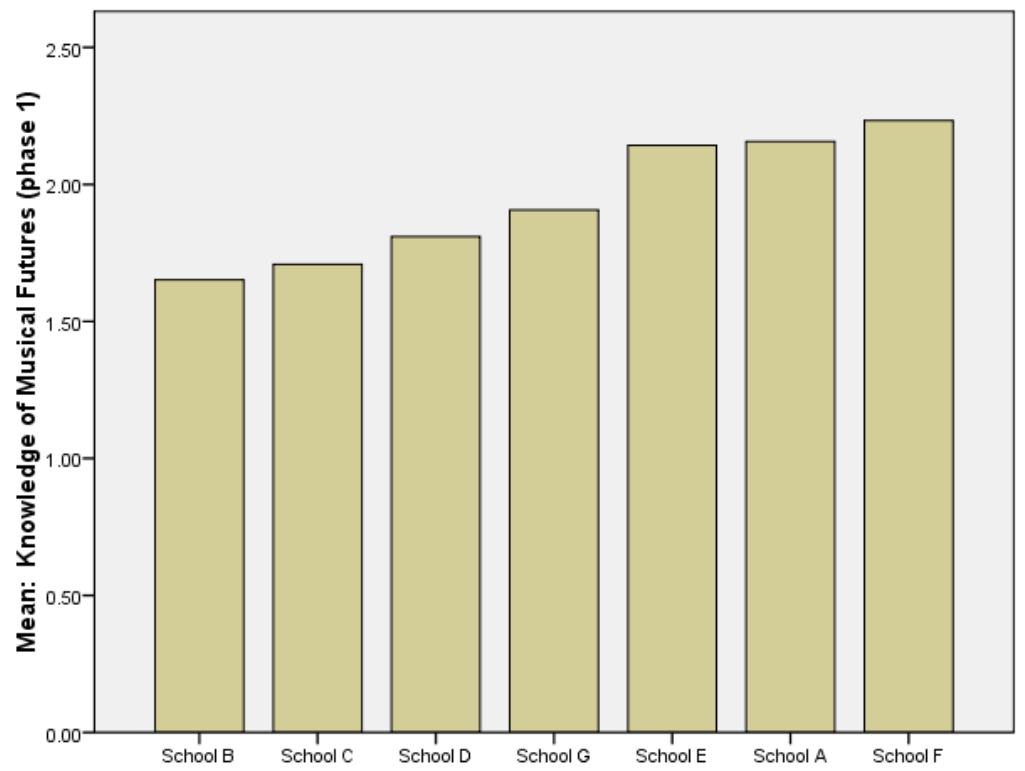

The data collected from the non-music staff during Phases 2 and 3 indicated that general awareness of Musical Futures within the schools had increased. Table 2 shows, for example, that at Phase 1 just 5.3\% of non-music staff reported that they knew 'a lot' about Musical Futures. This increased to $11.4 \%$ in Phase 2 and $9.3 \%$ in Phase 3 . Analysis of variance showed no statistically significant differences between schools at Phase 2 or Phase 3.

Table 2: Awareness of Musical Futures amongst non-music staff

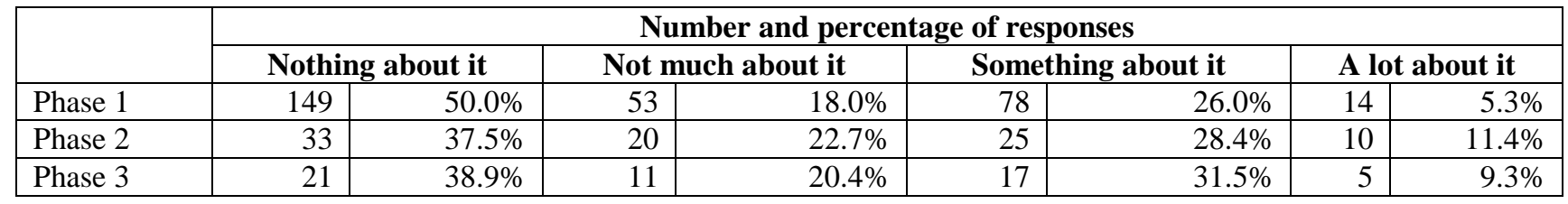

\section{Impact on the school}

Overall, in the first phase of data collection $78 \%$ of non-music staff indicated that Musical Futures had had a positive impact on the school. $73 \%$ indicated that it had had a positive impact on student motivation, $59 \%$ on student well-being, $74 \%$ on student self-esteem, $77 \%$ on encouraging students to work together, $72 \%$ on student confidence, and $57 \%$ on encouraging students to work without help. Thirty nine percent agreed that Musical Futures had improved student concentration, $41 \%$ that it had encouraged students to be organised, $39 \%$ that it had improved students attitudes towards learning in general, and $45 \%$ that it had had a positive impact on student progression (see Table 3 ). 
Analysis of variance showed that there were statistically significant differences between schools in responses to each of these statements with the exception of the general statement about the positive impact on school (see Table 4) 
Table 3: Perceived impact of Musical Futures across the school (Phase 1)

\begin{tabular}{|l|c|c|c|c|c|c|}
\hline & \multicolumn{3}{|c|}{ Number and percentage of responses } & *Mean & SD \\
\cline { 2 - 5 } & $\begin{array}{c}\text { Strongly } \\
\text { agree }\end{array}$ & Agree & Unsure & Disagree & & \\
\hline $\begin{array}{l}\text { Overall Musical Futures has had a positive } \\
\text { impact on this school }\end{array}$ & $25 \%(37)$ & $53 \%(79)$ & $21 \%(32)$ & $.7 \%(1)$ & 4.0 & .7 \\
\hline $\begin{array}{l}\text { Musical Futures has had a positive impact } \\
\text { on student motivation }\end{array}$ & $18 \%(26)$ & $55 \%(81)$ & $26 \%(38)$ & $.7 \%(2)$ & 3.9 & .7 \\
\hline $\begin{array}{l}\text { Musical Futures has had a positive impact } \\
\text { on student well-being }\end{array}$ & $14 \%(20)$ & $45 \%(66)$ & $41 \%(60)$ & $.7(1)$ & 3.7 & .7 \\
\hline $\begin{array}{l}\text { Musical Futures has had a positive impact } \\
\text { on student self-esteem }\end{array}$ & $19 \%(28)$ & $55 \%(81)$ & $24 \%(36)$ & $1.4(2)$ & 3.9 & .7 \\
\hline $\begin{array}{l}\text { Musical Futures has encouraged students } \\
\text { to work tougher }\end{array}$ & $28 \%(41)$ & $49 \%(72)$ & $23 \%(34)$ & $.7(1)$ & 4.0 & .7 \\
\hline $\begin{array}{l}\text { Musical Futures has increased students' } \\
\text { confidence }\end{array}$ & $24 \%(35)$ & $48 \%(70)$ & $29 \%(42)$ & & 3.9 & .7 \\
\hline $\begin{array}{l}\text { Musical Futures has encouraged students } \\
\text { to work without help }\end{array}$ & $19 \%(28)$ & $38 \%(57)$ & $41 \%(61)$ & $1.4(2)$ & 3.8 & .8 \\
\hline $\begin{array}{l}\text { Musical Futures has improved students } \\
\text { concentration }\end{array}$ & $8 \%(12)$ & $31 \%(46)$ & $59 \%(87)$ & $2 \%(3)$ & 3.4 & .7 \\
\hline $\begin{array}{l}\text { Musical Futures has encouraged students } \\
\text { to be organised }\end{array}$ & $6 \%(9)$ & $35 \%(51)$ & $55 \%(82)$ & $4 \%(6)$ & 3.4 & .7 \\
\hline $\begin{array}{l}\text { Musical Futures has improved students' } \\
\text { attitudes to learning in general }\end{array}$ & $7 \%(10)$ & $32 \%(48)$ & $59 \%(87)$ & $2 \%(3)$ & 3.4 & .6 \\
\hline $\begin{array}{l}\text { Musical Futures has had a positive impact } \\
\text { on student progression }\end{array}$ & $8 \%(12)$ & $37 \%(55)$ & $54 \%(80)$ & $.7 \%(1)$ & 3.5 & .7 \\
\hline
\end{tabular}

*Mean score: 1 = strongly disagree, 2 = disagree, 3 = unsure, $4=$ agree, $5=$ strongly agree

$*$ Numbers in brackets indicate the number of responses

Table 4: School differences in perceptions of impact on students (Phase 1)

\begin{tabular}{|c|c|c|c|c|c|c|c|c|c|c|}
\hline & \multicolumn{9}{|c|}{$\begin{array}{l}\text { Mean score: } \\
1=\text { strongly disagree, } 2=\text { disagree, } 3=\text { unsure, } 4=\text { agree, } 5= \\
\text { strongly agree }\end{array}$} & \multirow[b]{2}{*}{ SIG } \\
\hline & $\mathbf{A}$ & B & $\mathbf{C}$ & D & $\mathbf{E}$ & $\mathbf{F}$ & G & $\mathbf{Y}$ & \begin{tabular}{|l|} 
overall \\
\end{tabular} & \\
\hline $\begin{array}{l}\text { Overall Musical Futures has had a positive } \\
\text { impact on this school }\end{array}$ & 4.3 & 4.1 & 4.0 & 4.1 & 3.8 & 4.1 & 4.7 & 3.8 & 4.0 & NS \\
\hline $\begin{array}{l}\text { Musical Futures has had a positive impact } \\
\text { on student motivation }\end{array}$ & 4.4 & 3.8 & 3.5 & 4.0 & 3.8 & 4.0 & 4.7 & 3.7 & 3.9 & .001 \\
\hline $\begin{array}{l}\text { Musical Futures has had a positive impact } \\
\text { on student well-being }\end{array}$ & 4.2 & 3.8 & 3.3 & 3.8 & 3.6 & 3.9 & 3.7 & 3.4 & 3.7 & .01 \\
\hline $\begin{array}{l}\text { Musical Futures has had a positive impact } \\
\text { on student self-esteem }\end{array}$ & 4.4 & 3.9 & 3.6 & 4.0 & 3.8 & 4.1 & 4.3 & 3.7 & 3.9 & .004 \\
\hline $\begin{array}{l}\text { Musical Futures has encouraged students to } \\
\text { work tougher }\end{array}$ & 4.6 & 4.0 & 3.8 & 3.8 & 4.0 & 4.1 & 4.3 & 3.8 & 4.0 & .009 \\
\hline $\begin{array}{l}\text { Musical Futures has increased students' } \\
\text { confidence }\end{array}$ & 4.4 & 4.0 & 3.7 & 4.0 & 3.8 & 4.0 & 4.7 & 3.6 & 3.9 & .006 \\
\hline $\begin{array}{l}\text { Musical Futures has encouraged students to } \\
\text { work without help }\end{array}$ & 4.3 & 3.7 & 3.6 & 3.6 & 3.8 & 3.6 & 4.0 & 3.4 & 3.8 & .05 \\
\hline $\begin{array}{l}\text { Musical Futures has improved students } \\
\text { concentration }\end{array}$ & 3.8 & 3.6 & 3.2 & 3.5 & 3.4 & 3.5 & 3.3 & 3.1 & 3.4 & .04 \\
\hline $\begin{array}{l}\text { Musical Futures has encouraged students to } \\
\text { be organised }\end{array}$ & 3.8 & 3.7 & 3.1 & 3.5 & 3.3 & 3.5 & 3.7 & 3.1 & 3.4 & .002 \\
\hline $\begin{array}{l}\text { Musical Futures has improved students' } \\
\text { attitudes to learning in general }\end{array}$ & 3.7 & 3.6 & 3.2 & 3.6 & 3.2 & 3.8 & 3.0 & 3.2 & 3.4 & .002 \\
\hline $\begin{array}{l}\text { Musical Futures has had a positive impact } \\
\text { on student progression }\end{array}$ & 3.9 & 3.6 & 3.3 & 3.5 & 3.4 & 3.7 & 3.3 & 3.2 & 3.5 & .017 \\
\hline
\end{tabular}


When the schools were revisited in Phase 2 of the research, 88 non-music staff completed the same questionnaire. Overall, the responses from the Phase 2 sample of non-music staff were more positive than the Phase 1 responses, with higher mean scores for each of the statements (see Table 5). Only one teacher disagreed with any of the statements, indicating disagreement with the statement that Musical Futures improved students' attitudes to learning in general. The highest mean scores were in relation to the statements that Musical Futures had helped students to learn to work together $(M=4.3)$, had a positive impact on student self confidence $(M=4.2)$ and self esteem $(\mathrm{M}=4.1)$ and had a positive impact on the school, generally $(\mathrm{M}=4.2)$. No statistically significant differences between schools were found, with regard to the non-music staff responses in Phase 2.

Table 5: Perceived impact of Musical Futures across the school (Phase 2)

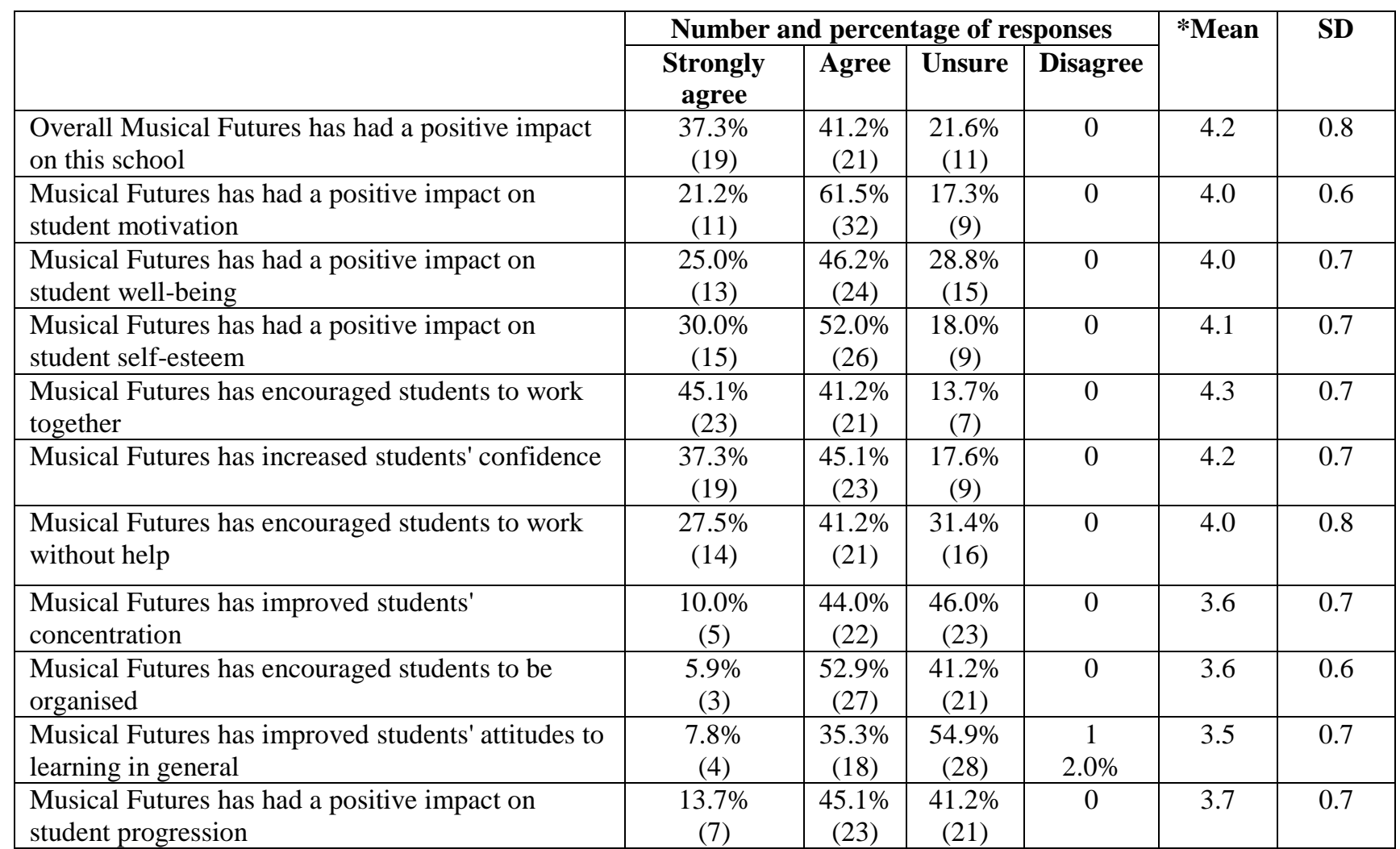

*Mean score: 1 = strongly disagree, 2 = disagree, 3 = unsure, $4=$ agree, 5 = strongly agree

* Numbers in brackets indicate the number of responses

When the schools were revisited in Phase 3, there were no negative responses to any of the items on the questionnaire. No statistically significant differences between schools were found, with regard to the non-music staff responses in Phase 3. The most positive responses were with regard to Musical Futures helping students to work together and enhancing student motivation. The most 
ambivalence was with regard to whether Musical Futures had supported students in their learning more generally or with transferable skills such as concentration and organisation (see Table 6).

Table 6: Perceived impact of Musical Futures across the school (Phase 3)

\begin{tabular}{|c|c|c|c|c|c|}
\hline & \multicolumn{3}{|c|}{$\begin{array}{l}\text { Number and percentage of } \\
\text { responses }\end{array}$} & \multirow[t]{2}{*}{ *Mean } & \multirow[t]{2}{*}{ SD } \\
\hline & $\begin{array}{l}\text { Strongly } \\
\text { Agree }\end{array}$ & Agree & Unsure & & \\
\hline $\begin{array}{l}\text { Overall Musical Futures has had a positive impact on this } \\
\text { school }\end{array}$ & $\begin{array}{c}21.2 \% \\
(7)\end{array}$ & $\begin{array}{l}48.5 \% \\
(16)\end{array}$ & $\begin{array}{c}30.3 \% \\
(10)\end{array}$ & 3.9 & 0.7 \\
\hline $\begin{array}{l}\text { Musical Futures has had a positive impact on student } \\
\text { motivation }\end{array}$ & $\begin{array}{l}24.2 \% \\
(8)\end{array}$ & $\begin{array}{c}48.5 \% \\
(16)\end{array}$ & $\begin{array}{c}27.3 \% \\
(9)\end{array}$ & 4.0 & 0.7 \\
\hline $\begin{array}{l}\text { Musical Futures has had a positive impact on student well- } \\
\text { being }\end{array}$ & $\begin{array}{c}12.1 \% \\
(4)\end{array}$ & $\begin{array}{c}39.4 \% \\
(13)\end{array}$ & $\begin{array}{c}48.5 \% \\
(16)\end{array}$ & 3.6 & 0.7 \\
\hline $\begin{array}{l}\text { Musical Futures has had a positive impact on student self- } \\
\text { esteem }\end{array}$ & $\begin{array}{l}21.2 \% \\
(7)\end{array}$ & $\begin{array}{c}42.4 \% \\
(14)\end{array}$ & $\begin{array}{c}36.4 \% \\
(12)\end{array}$ & 3.8 & 0.8 \\
\hline Musical Futures has encouraged students to work together & $\begin{array}{c}27.3 \% \\
(9( \\
\end{array}$ & $\begin{array}{c}51.5 \% \\
(17)\end{array}$ & $\begin{array}{c}21.2 \% \\
(7)\end{array}$ & 4.1 & 0.7 \\
\hline Musical Futures has increased students' confidence & $\begin{array}{c}21.9 \% \\
(7)\end{array}$ & $\begin{array}{c}40.6 \% \\
(13)\end{array}$ & $\begin{array}{c}37.5 \% \\
(12)\end{array}$ & 3.8 & 0.8 \\
\hline $\begin{array}{l}\text { Musical Futures has encouraged students to work without } \\
\text { help }\end{array}$ & $\begin{array}{l}21.2 \% \\
(7)\end{array}$ & $\begin{array}{c}27.3 \% \\
(9)\end{array}$ & $\begin{array}{c}51.5 \% \\
(17)\end{array}$ & 3.7 & 0.8 \\
\hline Musical Futures has improved students' concentration & $\begin{array}{l}6.1 \% \\
(2)\end{array}$ & $\begin{array}{c}21.2 \% \\
(7)\end{array}$ & $\begin{array}{l}72.7 \% \\
(24)\end{array}$ & 3.3 & 0.6 \\
\hline Musical Futures has encouraged students to be organised & $\begin{array}{c}9.4 \% \\
(3)\end{array}$ & $\begin{array}{c}34.4 \% \\
(11)\end{array}$ & $\begin{array}{c}56.2 \% \\
(18) \\
\end{array}$ & 3.5 & 0.7 \\
\hline $\begin{array}{l}\text { Musical Futures has improved students' attitudes to } \\
\text { learning in general }\end{array}$ & $\begin{array}{l}12.1 \% \\
(4)\end{array}$ & $\begin{array}{l}21.2 \% \\
(7)\end{array}$ & $\begin{array}{l}63.6 \% \\
(21)\end{array}$ & 3.4 & 0.8 \\
\hline $\begin{array}{l}\text { Musical Futures has had a positive impact on student } \\
\text { progression }\end{array}$ & $\begin{array}{c}9.1 \% \\
(3)\end{array}$ & $\begin{array}{c}33.3 \% \\
(11)\end{array}$ & $\begin{array}{l}57.6 \% \\
(19)\end{array}$ & 3.9 & 0.7 \\
\hline
\end{tabular}

*Mean score: 1 = strongly disagree, 2 = disagree, 3 = unsure, 4 = agree, $5=$ strongly agree

* Numbers in brackets indicate the number of responses

Changes over time were explored (see Table 7) drawing on data from staff who had completed the questionnaire more than once. The only statistically significant change was with regard to the statement suggesting that Musical Futures had improved students' attitudes to learning in general. There was less agreement in Phase 2 than Phase $1(p=.02)$. 
Table 7: Perceived impact of Musical Futures across the school (changes over time)

\begin{tabular}{|c|c|c|c|c|}
\hline & \multicolumn{2}{|c|}{$\begin{array}{c}\text { Longitudinal non-music } \\
\text { staff sample } 1 \text { : } \\
n=44\end{array}$} & \multicolumn{2}{|c|}{$\begin{array}{l}\text { Longitudinal non-music } \\
\text { staff sample } 2: n=23\end{array}$} \\
\hline & $\begin{array}{l}\text { *Mean: } \\
\text { Phase 1 }\end{array}$ & $\begin{array}{l}\text { Mean: } \\
\text { Phase } 2\end{array}$ & $\begin{array}{l}\text { Mean: } \\
\text { Phase 1 }\end{array}$ & $\begin{array}{l}\text { Mean: } \\
\text { Phase } 3\end{array}$ \\
\hline $\begin{array}{l}\text { Overall Musical Futures has had a positive impact on this } \\
\text { school }\end{array}$ & \multicolumn{2}{|c|}{$\begin{array}{l}\text { N/A: not enough } \\
\text { responses in Phase } 2 \text { to } \\
\text { carry out a comparison }\end{array}$} & 3.6 & 3.9 \\
\hline $\begin{array}{l}\text { Musical Futures has had a positive impact on student } \\
\text { motivation }\end{array}$ & 4.1 & 4.2 & 3.9 & 4.1 \\
\hline $\begin{array}{l}\text { Musical Futures has had a positive impact on student well- } \\
\text { being }\end{array}$ & 3.9 & 4.1 & 3.9 & 3.6 \\
\hline $\begin{array}{l}\text { Musical Futures has had a positive impact on student self- } \\
\text { esteem }\end{array}$ & 4.2 & 4.2 & 4.0 & 3.9 \\
\hline Musical Futures has encouraged students to work together & 4.2 & 4.4 & 4.3 & 4.3 \\
\hline Musical Futures has increased students' confidence & 4.1 & 4.2 & 4.1 & 4.1 \\
\hline $\begin{array}{l}\text { Musical Futures has encouraged students to work without } \\
\text { help }\end{array}$ & 3.9 & 4.0 & 4.0 & 3.9 \\
\hline Musical Futures has improved students' concentration & 3.7 & 3.6 & 3.6 & 3.4 \\
\hline Musical Futures has encouraged students to be organised & 3.7 & 3.6 & 3.5 & 3.5 \\
\hline $\begin{array}{l}\text { Musical Futures has improved students' attitudes to learning } \\
\text { in general }\end{array}$ & 3.8 & $* * 3.4$ & 3.6 & 3.5 \\
\hline $\begin{array}{l}\text { Musical Futures has had a positive impact on student } \\
\text { progression }\end{array}$ & 3.9 & 3.7 & 3.6 & 3.4 \\
\hline
\end{tabular}

*Mean score: 1 = strongly disagree, $2=$ disagree, $3=$ unsure, $4=$ agree, $5=$ strongly agree

$* *$ Change over time was statistically significant $(\mathrm{p}=.02)$

\section{Perceptions of Musical Futures in the case study schools}

This section sets out the findings from the interviews with members of the senior management teams in the schools.

In School A, Musical Futures work was well known in the school. The head teacher articulated how the broad principles of Musical Futures supported the overall aims of the school as :

'An approach which fully involves all the children (sic) participating. An approach to teaching which gives a lot of independence, puts a huge amount into the cross curricular skills that we really need to develop, team work, creativity, resilience, higher level thinking skills, and an approach that is just great fun.' (Head teacher)

As the school moved towards the personalisation of learning Musical Futures provided an illustration of how this could work. The school was described as inclusive, valuing diversity and the 
individual and providing the kind of learning environment where everyone could succeed. The fast pace of change meant that students needed to learn to be adaptive, creative and resilient. The work in Musical Futures was seen to reflect this being:

'a microcosm of that because they just keep going, they interrelate with the staff, suggest how work could be improved, have another go at it, and the resilience and the stamina to keep going has become an integral part of the teaching approach and so - the whole issue of transferability, resilience, creativity, team work, judging when to independent and when to be a member of the team is developing very nicely.' (Head teacher)

The head teacher indicated that this was the kind of approach that he wanted to develop more widely in the school:

I want to link across the school the problem-solving approach, and again the approach that the music team are using encapsulates that completely. So it's got everything we want as a teaching approach.' (Head teacher)

The Musical Futures experience was perceived to exemplify student-centric, inclusive teaching involving:

'Genuine activity around genuine problems around genuine challenges. I see active involvement of all of the children, different talents, different levels of expertise but full involvement of all the children, with a teacher who is being used by the children as a resource rather than as a dictator of content.' (Head teacher)

The success of the Musical Futures approach was celebrated in a variety of ways including students showcasing their work at staff briefings which the head teacher believed contributed to developing a 
more communicative working environment with the dissemination of the kind of pedagogical approach that he believed would benefit the students:

'In one meeting a group of 30 Year 9 musicians came in and played Teenage Kicks. It was just fantastic because the departments within the school are very isolationist and these meetings provide an awareness of all the good work that's happening. I think Musical Futures has played a real part in that because it's helping exactly the kind of ethos I want to develop in the school. Can do, will do, and will have fun doing it.' (Head teacher)

There were some tensions in the school when difficult students were rewarded for good work in non-academic subjects. However, the head believed that this was the way forward 'building on what they're good at, to give them opportunities to succeed. If we take five steps forward and four steps back, we're still heading in the right direction.'

Overall, Musical Futures was seen as being greatly enjoyed by the students and associated with increased motivation, self-worth and autonomy. It enabled students to reach very high standards and increased take up at Key Stage 4 and engagement in extra-curricular activities. The department was viewed as setting 'a very good example in terms of school development'.

In School B, an all boys' school which reflected the needs and interests of the local community, Musical Futures was seen to fit with the school ethos of valuing the individual while promoting achievement and providing the broadest possible educational experience. Musical Futures was perceived as successful in terms of 'take-up, interest, enthusiasm, and engagement of students in their learning.' The emphasis on team work, autonomy, focus and concentration and the outcomes in terms of confidence and enhanced self-esteem was viewed as a model for other subjects in the school. The school was moving towards assessing the whole student through a portfolio approach including academic skills, attendance, behaviour, clubs, extra-curricular responsibilities, team work, 
and independent work. Musical Futures fit well with this. The Deputy Head pointed out that Musical Futures practice led to:

'Autonomous and genuinely collaborative work. I mean sometimes people say they're doing group work but that means the boys are sitting round the same table, but this is really collaborative stuff. It hits the Personal Learning and Thinking Skills agenda which is very important. It also supports very general things like development of concentration, attention, sense of taking responsibility for their own learning, all of those things.' (Deputy Head Teacher)

The approach also provided a model of how to provide feedback to students:

' We've done a lot of work in looking at the performing arts in general and indeed music in particular for good practice in effective feedback, because there's a lot of very, very effective oral feedback, not just from the teacher but in terms of self-assessment and peer-assessment so that all supports a whole huge tranche of the stuff we do as a whole school'.

The approach was also viewed as extremely positive in terms of the Ofsted criteria of 'good' and 'outstanding' lessons:

'When you look at a typical lesson, the people who are doing the hardest work are the students, whereas in some lessons the person working the hardest is the teacher. I think that's the difference between a good lesson and an outstanding lesson so I think there's great potential for us learning from that.' (Deputy Head Teacher)

School C was a high achieving school with up to $95 \%$ of students getting 5 A-C grades at GCSE and $83 \%$ with English and Maths. In music, the pass rate was higher with an average pass rate of 
$98 \% \mathrm{~A}^{*}$-C over four years. Despite this the head teacher reported that there were some students who previously had not engaged well with school music:

'Through music we've gone from a situation where we had elite very capable musicians working together, the school orchestra, wind band, working well together, but other kids not really feeling part of music, music events being rather poorly supported by the general student body, it not being really seen as cool and not really relevant to their everyday life to a situation...... Musical Futures has allowed a sort of liberation away from what was a very prescribed and rather dull delivery and has made a difference to the students' perception of music.' (Head Teacher)

Experience of Musical Futures had led to a doubling of the numbers of students taking music at Key Stage 4 and there had also been very positive feedback from parents. It was seen as 'inspiring'. It also made a major contribution to the development of transferable skills in the students:

'There's no doubt if you see students working in a Musical Futures environment where they're having to collaborate, compromise, seek agreement, put up with other people, organise themselves to get something done to deliver something by a certain time, all these things are incredibly useful life skills. There's no doubt that the skills that they're practising and rehearsing are very applicable elsewhere in both school and life.' (Head teacher)

However, the Head Teacher indicated that not all of the music staff found adopting an informal learning approach comfortable and some found it difficult to implement:

'Not all staff have found that easy, particularly not being in control. This is very much a student empowering thing, right, off you go and do it, and the kind of organisation to bring that back together is really quite challenging. ' (Head teacher) 
School D served a very deprived area, with many students from minority ethnic groups, and many with difficulties with literacy and numeracy. The school had a supportive ethos and tried to help all students to achieve to their best. Music was seen to transcend some of the cultural barriers. Musical Futures in particular was seen to support the development of collaborative learning:

'One of the skills that we particularly want our youngsters to develop are the skills of working collaboratively together and we've got a focus at the moment on trying to change methods of learning so that students are engaged more in learning by working with others. Music is an ideal opportunity for them to do that.' (Deputy Head)

With many students from minority ethnic groups in the school there was also a need to develop the language skills of students. Musical Futures was seen as a way of achieving this:

'In areas like music where they're engaged, where they have to think more creatively, they have to talk to each other, actively participate. That's obviously going to improve their language skills. And speaking and listening is particularly an area we're trying to encourage in other areas of the curriculum. So that's something where music can make quite a contribution.' (Deputy Head)

Musical Futures was also seen to offer opportunities for students to succeed when they might be experiencing difficulties academically:

'I can think of two students in particular, one of whom had massive learning problems through dyslexia who was highly talented in music and another student who had to grapple with quite a lot of emotional problems because of personal difficulties away from school and dealt with many of those problems through experiencing music through Musical Futures.' (Deputy Head) 
School E had as a key aim meeting the Every Child Matters agenda and Excellence for All recognising that every student was unique and tailoring teaching to meet their needs. This involved putting student well-being first and enabling students to reach their potential. The school was open to trying new approaches to teaching and learning. Musical Futures was perceived to have contributed by presenting different ways of conceptualising learning and teaching. The approach had been presented at staff conferences so that staff understood how it operated, the nature of independent learning, and how the groups functioned. However, although Musical Futures was seen to have merit in relation to students taking responsibility for their work and supporting each other, some staff viewed the approach as too innovative. This resistance was exacerbated when staff

'walk through the school and see students banging on things and just what basically appears to be causing riots and rackets in the sense that they're not in a controlled environment. Staff wonder whether or not you can class that as learning. Then because they don't see the entire process, just a snapshot of it which doesn't reflect what is really going on staff struggle to understand what it's all about. The other challenge is that people see it and say OK that's very interesting, but it wouldn't apply to my subject area.' (Head of teaching and learning)

There was recognition that the students 'absolutely love it, really, really enjoy it. What I'm seeing is students taking a piece of music and just totally reinventing it and rejuvenating it in whichever way they prefer.' (Line manager music).

The school had seen an increase in the uptake of music at Key Stage 4 with about a fifth of the year taking music as an option.

School F served a local catchment area where students came from a range of different backgrounds and different faiths. The ethos was one of dignity and respect, to value every student, to ensure they that they felt safe and could achieve and attain according to their unique talents and abilities. 
Musical Futures was seen to contribute because it helped to identify talent and provide encouragement and opportunity. There was an emphasis in the school on performance and Musical Futures had increased the confidence of students in relation to this. They were perceived as more willing to come forward and, when they performed, were perceived to do so with great skill. The programme was also seen to encourage independent learning, team work, creativity, and concentration and enhance self-esteem. It also contributed to an increase in take up of music at Key Stage 4 and higher attainment levels. The Deputy Head Teacher indicated that Musical Futures contributed to the way that students perceived themselves as able to achieve:

'... in relation to Musical Futures, there's something about the aspirational feeling in the school which is that you can achieve, you can do well ... It's about taking a child who perhaps hasn't had experience of music in their home life or their family background saying you could do this so it contributes to the am I capable, and am I lovable ... it's about investing in them...... There are students who without Musical Futures wouldn't have performed in assembly for example previously.' (Deputy Head Teacher)

Musical Futures had appeared on the agenda at leadership meetings and the music department was viewed as outgoing and engaging in activities across the school. There was speculation about the extent to which Musical Futures impacted on the other creative activities in the school but no examples were offered.

\section{Discussion}

There are of course limitations to this research. It was undertaken in Musical Futures champion schools where staff were more likely to have knowledge about Musical Futures and perhaps be more supportive of it than teachers in other schools. The design of the Likert scale statements, which were framed positively, may also have influenced responses, although there was variability in the extent of agreement with different statements suggesting that respondents were responding 
thoughtfully. The interview sample, drawn from the schools' Senior Management Teams, was relatively small and as they were drawn from Musical Futures Champion Schools this may have influenced responses, although interviewees were not only supportive but also critical of the approach.

A relatively small proportion of non-music staff indicated that they were aware of the Musical Futures approach. This is not surprising. There is no reason why non-music staff should have had knowledge of the approach. In fact, it is likely that working in a Musical Futures Champion School elevated the level of positive response. While at the time of the Phase 1 data collection, many staff knew little or nothing about Musical Futures, this changed over the course of the subsequent two years, with a notable increase in awareness between Phase 1 and Phase 2. While there were considerable differences between schools at Phase 1, almost certainly depending on the speed with which school Senior Management Teams had disseminated information about the approach, no significant differences between schools were found in subsequent phases. Overall, the percentage of staff knowing about the approach continued to be relatively small throughout the research, which suggests that it was not at the time of the research having a major impact on the introduction of a more student centred pedagogy across the school.

Many non-music staff and members of Senior Management Teams indicated that Musical Futures had had a positive impact on students enhancing motivation, well-being, self-esteem, confidence, and collaborative and independent working with some impact on transferable skills including concentration and organisation, and students' attitudes towards school and their progress. These findings reflect those of other evaluations of Musical Futures (see Benson, 2012; Evans, Beauchamp \& John, 2015; Jeanneret, 2010; Jeanneret et al., 2011; John \& Evans, 2013; Ofsted, 2006; O’Neill \& Bespflug, 2011; Younker et al., 2012). 
Senior managers in the school valued Musical Futures for the way it had generated enthusiasm for music, had increased uptake at Key Stage 4 and was providing opportunities for developing transferable skills and meeting the personalised learning agenda. There was variability in the extent to which it was perceived as having had an impact on teaching in other subjects. In some schools it was seen as leading the way in developing a more student-centred approach, offering a way to meet the needs for personalised learning across the whole curriculum and addressing general behaviour issues in relation to group work. However, teachers in other subjects often found it difficult to relate to the Musical Futures work because the students seemed not to be learning and the process appeared 'chaotic', There was a recognition by some members of Senior Management that for many teachers, including some music teachers, the perceived loss of control in the classroom was challenging. Fears related to losing control of classrooms may be a key barrier to general acceptance and support for the kinds of approaches advocated by Musical Futures by the wider teaching profession. Given that the schools participating in the research were Musical Futures Champion Schools where senior management were generally supportive of the approach, the barriers for adopting the approach and applying it across the curriculum more widely may be challenging or even insurmountable, particularly in the performativity culture in the UK (Ball, 2003), although one senior leader acknowledged that the level of engagement of students in Musical Futures met the criteria for an 'outstanding' grade in Ofsted inspections.

Members of senior management referred to the benefits for particular groups of students in terms of the inclusion of those with Special Educational Needs and the way that group work supported the development of language skills in those with English as a second language. However, the inclusion of students with difficult behaviour and their receiving rewards for good work in music was not always viewed positively by other teachers.

No issues were raised in the research in relation to inclusion in musical terms. This is in contrast to the Scandinavian research which indicated that informal approaches designed to reflect the musical 
interests of all students failed because of the variety of musical interests that they had and the fast changing nature of 'popular' music (Vakeva, 2010). While it might be possible for teachers to have a superficial knowledge of a wide range of musical styles and genres it is not realistic for them to acquire even limited expertise in how to perform them. Each musical style and genre has its own language and technical requirements and acquiring these takes time and effort, even when high level musical skills have been acquired in other genres (Sudnow, 1978/1993). Students themselves do not expect teachers to actively engage in what they perceive as their music. Jaffurs (2004) found in her study of a student rock band that while the students appreciated her interest in their work they did not see her as being able to practice their craft. Teachers need to learn to be able to facilitate learning even when they do not have detailed knowledge of the genre. Wright and Kanellopoulos (2010) suggest that improvisation might provide a suitable vehicle for them to develop understanding of the processes involved in informal learning supporting the development of facilitative skills.

While there are indications from the current research that the informal learning approach adopted by Musical Futures is effective in generating a range of benefits which go beyond musical skills the research from Scandinavia raises issues about long-term musical outcomes. It is important in considering this to distinguish between the Musical Futures approach focusing on learning informally with teachers acting as facilitators and the genre of popular music which is the means of its implementation. The simplest definitions of formal and informal learning define them in terms of location, aims and certification (Eraut, 2000). These criteria are not helpful in considering the nature of formal and informal pedagogy. To address this, Allsup (2008) distinguishes between informal learning and informalism arguing that the latter does not automatically lead to openness and democratic thinking and practice in the classroom. Folkestad (2006) defines formal learning situations as those where the activity is sequenced beforehand, usually by a teacher, who leads, organises and manages the activities. In contrast, informal learning is not sequenced beforehand. The activity and the interaction between the participants steer the process, while the learning is self- 
chosen and voluntary. Four elements are taken into account when considering the nature of the learning: the situation; learning style; ownership; and intentionality. He argues that the relationship between formal and informal learning should be viewed as a continuum not a dichotomy. Other authors support the notion that the intersection between formal and informal music education is not clear (Prouty, 2002) and that there is interplay between them (Jaffurs, 2004). This reflects the ways in which human beings learn. Learning may be deliberate and intentional or incidental, much occurring without our conscious awareness (Blakemore and Frith, 2000). For instance, when we hear music we process an enormous amount of information rapidly and effortlessly because we have internal representations developed from our previous cultural experiences (Dowling, 1993). This knowledge is implicit, learned through exposure to particular environments, and is applied automatically whenever we listen to music. This process begins in the womb (Parncutt, 2006). Given the ease with which human beings learn music incidentally, it would seem logical that informal learning processes should be adopted in schools. However, these do not need to be limited to popular music. Depending on the genre, some level of formal instrumental tuition may be needed to support the development of basic instrumental skills but once acquired, students can utilise these to work on projects of their choice using informal methods.

A further issue for the implementation of Musical Futures in the classroom relates to the way that formalising the teaching of specific musical genres can lead to codification, with a loss of creativity and individuality. This has been seen with the formalisation of jazz where teachers tend to use the same approaches, with students learning the same music, the same patterns and the same recordings (Gatien, 2012). This can lead to musicians being thoroughly prepared but in skills that are not always aligned with what is expected in the profession (Cain, 2007).

To conclude, Musical Futures has demonstrated the potential of informal learning techniques to enhance student motivation and promote the development of a wide range of transferable skills. Its focus in its implementation on popular music has been a strength in increasing the interest of 
students previously not actively engaged in making music, but, as has been identified in the Nordic countries, is also a weakness in that it limits the extent to which students can make musical progress.

\section{References}

ALLSUP, R. (2008) Creating an educational framework for popular music in public schools: Anticipating the second-wave. Visions of Research in Music Education, 12. http://www.usr.rider.edu/-vrme/v12n1/vision/1\%20AERA\%20-\%20Allsup.pdf

BALL, S. J. (2003) The teacher's soul and the terrors of performativity. Journal of Educational Policy, 18(2), 215-28.

BENSON, F. (2012) Thrown in at the deep end: Informal learning in a primary music classroom. Unpublished undergraduate thesis, Sydney Conservatorium of Music, University of Sydney.

BERGMAN, A. (2009) Vaxa upp med music: ungdomars musikanvandande $i$ skolan och pa fritiden (Growing up with music. Young people's use of music in school and during lesson time. $\mathrm{PhD}$ Dissertation, University of Gothenburg.

BLAKEMORE, S.J. \& FRITH, U. (2000) The implications of recent developments in neuroscience for research on teaching and learning. London: Institute of Cognitive Neuroscience.

BRAUN, V. and CLARKE, V. (2006).Using thematic analysis in psychology, Qualitative Research in Psychology, 3, 77-101

CAIN, M. (2007) Redefining the other: Teaching delight in Cultural Variety, Journal for Music-inEducation, 1, 35-39.

D’AMORE, A. (2014) Ten Years of Musical Futures: Take, Use, Innovate, Share. London: Paul Hamlyn Foundation

DOWLING, W.J. (1993) 'Procedural and declarative knowledge in music cognition and education'. In T. J. TIGHE \& W.J. WILDING (Eds) Psychology and Music: The understanding of melody and rhythm (pp5-18) Hillsdale, N.J.: Erlbaum.

ERAUT, M. ( 2000) Non-formal learning and tacit knowledge in professional work. British Journal of Educational Psychology, 70(1), 113-136.

EVANS, S.E., BEAUCHAMP, G., \& JOHN, V. (2015) Learners' experience and perceptions of informal learning in Key Stage 3 music: a collective case study, exploring the implementation of Musical Futures in three secondary schools in Wales, Music Education Research, 17(1), 1-16.

FINNEY, J. \& PHILPOTT, C. (2010) Informal learning and meta-pedagogy in initial teacher education in England, British Journal of Music Education, 27(1), 7-19.

FOLKESTAD, G. (2006) Formal and Informal learning situations or practices vs formal and informal ways of learning. British Journal of Music Education, 23(2), 135-146. 
GATIEN, G. (2012) Categories and music transmission In S. Karlsen \& Vakeva, L (eds) Future Prospects for Music Education. Newcastle on Tyne: Cambridge Scholars Publishing (pp 53-78).

GEORGII-HEMMING, E (2006) Personal experiences and professional strategues. Music Education Research, 8(2), 217-36)

GEORGII-HEMMING, E. \& WESTVALL, M. (2010) Teaching music in our time. A study of student teachers' reflections on participation, inclusion and the right to musical development in their school-based music teacher education, Music Education Research, 12(4), 353-67.

GEORGII-HEMMING, E. \& WESTVALL, M. (2012) Music Education: A personal matter? Examining the current discourses of music education in Sweden. In S. KARSLEN \& L VAKEVA (eds) Future prospects for music education: Corroborating informal learning pedagogy. Newcastle on Tyne, UK: Cambridge Scholars Publishing (pp97-114).

GREEN, L. (2002) How Popular Musicians Learn: A Way Ahead for Music Education. Aldershot: Ashgate Publishing Ltd.

GREEN, L. (2008) Music, Informal Learning and the School: A New Classroom Pedagogy. Aldershot, Ashgate Publishing Ltd.

HALLAM, S., CREECH, A., SANDFORD, C., RINTA, T. \& SHAVE, K. (2008) Survey of Musical Futures. London: Institute of Education

JAFFURS, S.E. (2004) The impact of informal music learning practice in the classroom, or how I learned how to teach from a garage band, International Journal of Music Education, 22(3), 187200.

JEANNERET, N. (2010) Musical Futures in Victoria, Australian Journal of Music Education, 2, 148-164.

JEANNERET, N., MCLENNAN, R., \& STEVENS-BALLENGER, J. (2011) Musical Futures: An Australian Perspective Findings from a Victorian Pilot study. Melbourne Graduate School of Education, Melbourne University.

JOHN, V \& EVANS, S. (2013) Musical Futures: Summary of the Findings of the Wales Pilot 20112012. Doi. hpps://www.musicalfutures.org/resource/27964/title/musicalfutureswalespilot201112. Accessed 14-01-15

KARLSEN, S. \& VAKEVA, L. (2012) (eds) Future prospects for music education: Corroborating informal learning pedagogy. Newcastle on Tyne, UK: Cambridge Scholars Publishing.

MUSICAL FUTURES (2014) www.musicalfutures.org.uk Accessed 20-07-15

OFSTED (2006) An Evaluation of the Paul Hamlyn Foundation's Musical Futures Project (HMI 2682). London: Ofsted.

ORGANISATION FOR ECONOMIC COOPEARATION AND DEVELOPMENT (OECD) (2007) Activity on recognition of non-formal and informal learning. Pan-Canadian overview. Council of Minsters of Education, Canada. 
O’NEILL, S \& BESPFLUG, K. (2011) Musical Futures Comes to Canada: Engaging Students in Real-World Music Learning, Canadian Music Educator/ Musicien Educateur au Canada, 53(2), 25.

PARNCUTT, R. (2006) Prenatal development. In G.E. MCPHERSON (Ed). The child as Musician (pp. 1-31). Oxford: Oxford University Press.

PATTON, M.Q. (1990).Qualitative Evaluation and Research Methods ( $2^{\text {nd }}$ Ed). Newbury Park, CA: Sage

PAYNTER, J. (2000) Making progress with composing. British Journal of Music Education, 17(1), 5-31.

PROUTY, K.E. (2002) From storyville to State University. The interaction of academic and nonacademic learning cultures in post-secondary jazz education. Dissertation abstracts International, 64(1).

SKOLVERKET (Swedish National Agency for Education) (2004) Nationell utvardering av grundskolan 2003. Bild, him-och konsumentkunskap, idrott och halsa, music och slojd (National Evaluation of the Compulsory School in 2003. Subject Report.

http://www.skolverket.se/publikationer?id=1385

SLOBODA, J. (2001) 'Emotion, functuality, and the everyday experience of music: where does music education fit?. Music Education Research, 3(2), 243-254.

SUDNOW, D. (1978/1993) Ways of the hand: the organisation of improvised conduct. London: Routledge and Kegan Paul

STRAUSS, C. (1984) Beyond 'formal' vs 'informal' education. Uses of psychological theory in anthropological research, Ethos, 12(5), 195-222.

VAKEVA, L (2006) Teaching popular music in Finland: What's up, what's ahead. International Journal of Music Education, 24(2), 126-131.

VAKEVA, L (2010) Garage band or GarageBand ${ }^{\mathrm{R}}$ Remixing musical futures. British Journal of Music Education, 27(1), 59-71.

WRIGHT, R \& KANELLOPOULOS, P. (2010). Informal music learning, improvisation and teacher education. British Journal of Music Education, 27(1), 71-88.

YOUNKER, B.E, WRIGHT, R., LINTON, L., \& BEYNON, C. (2012). Tuning into the Future: Sharing Initial Insights about the 2012 Musical Futures Pilot Project in Ontario. Canadian Music Educator, 53(4), 14-18. 


\section{APPENDICES}

\section{Interview schedule for members of the Senior Management Team in the school}

1. Have you come across the term 'Musical Futures'?

2. Could you talk about your general impressions of Musical Futures as a teaching and learning approach in this school?

3. Has Musical Futures contributed to whole school ethos? If so, in what ways? Could you provide examples? What other contributions might it have made?

4. Has Musical Futures created any particular challenges for the school?

5. Could you comment on the impact of Musical Futures on progression in music or in other subjects?

6. Would you say that there have been any specific benefits for students involved in Musical Futures? If so, can you give some examples?

7. Could you comment on Musical Futures in terms of a) the school inspection process; b) other internal assessment processes?

8. Are there any other issues that you would like to raise? 